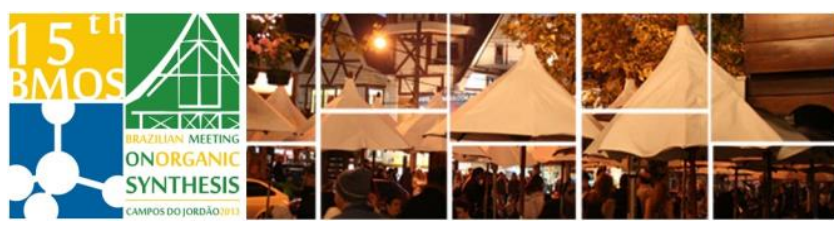

\title{
$\alpha$-Hydroxylation of malonates under mild reaction conditions
}

\author{
Marcos M. Peterle*, Marcelo V. Marques and Marcus M. Sá \\ Departamento de Química, Universidade Federal de Santa Catarina (UFSC), Florianópolis/SC, 88040-900 \\ *marcos.maragno@gmail.com
}

Keywords: Malonates, hydroxylation, oxone.

\section{INTRODUCTION}

Peroxysulfuric acid and its potassium salt have been known as oxidizing agents for some time. The potassium peroxymonosulfate salt, sold under the commercial name Oxone ${ }^{\circledR}\left(2 \mathrm{KHSO}_{5} \cdot \mathrm{KHSO}_{4} \cdot \mathrm{K}_{2} \mathrm{SO}_{4}\right)$, is a very stable substance and can be easily handled. Oxone has been used in the oxidation of alcohols and $\mathrm{C}-\mathrm{H}$ bonds, and also in the epoxidation of olefins. ${ }^{1}$ In this work, we present a simple method to prepare $\alpha$ hydroxy malonates of synthetic interest.

\section{RESULTS AND DISCUSSION}

For unsubstituted malonates 1a-c (Scheme 1), the hydroxylation of the $\alpha$-carbon was achieved in a short period (15 to 60 minutes) using the mild conditions ${ }^{2}$ presented in Table (entries 1-3). The ${ }^{1} \mathrm{H}$ NMR data show good conversion to the products $2 \mathrm{a}-\mathrm{c}$, although the recovery of $\mathbf{1 a}$ and $\mathbf{1 b}$ was difficult due to their solubility in water.

$$
\begin{aligned}
& \text { 1a-c } \\
& \mathrm{R}^{1}=\mathrm{CH}_{3}(\mathbf{a}) ; \mathrm{R}^{1}=\mathrm{CH}_{3} \mathrm{CH}_{2}(\mathbf{b}) ; \mathrm{R}^{1}=\mathrm{C}_{6} \mathrm{H}_{5} \mathrm{CH}_{2}(\mathbf{c})
\end{aligned}
$$

Scheme 1. Hydroxylation of unsubstituted malonates 1.

Malonates containing double bonds tethered to the $\alpha$ carbon, such as allyl (3a) and cinnamyl (3b), underwent epoxidation and hydroxylation in a single step (Scheme 2 and Table, entries 4 and 5).<smiles>[R]C=CCC(C(=O)O)C(=O)O</smiles>

3a $\mathrm{R}=\mathrm{H}, \mathrm{R}^{1}=\mathrm{CH}_{3} \mathrm{CH}_{2}$

3b R $=\mathrm{C}_{6} \mathrm{H}_{5}, \mathrm{R}^{1}=\mathrm{CH}_{3}$

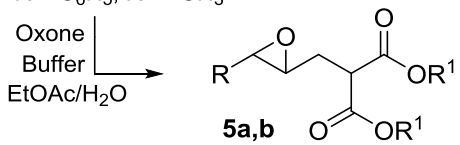

Scheme 2. Hydroxylation and epoxidation of allyl- (3a) and cinnamyl-substituted malonates (3b).

The hydroxylation of the allyl-substituted malonate $\mathbf{3 a}$ was not complete within 48 hours, giving a 1:1 mixture of epoxide $\mathbf{5 a}$ and hydroxylated epoxide $\mathbf{4 a}$. With cinnamyl-substituted malonate $\mathbf{3 b}$, the epoxidation with $\alpha$-hydroxylation occurred faster (4 hours) and with better conversion than with $\mathbf{3 a}$. Epoxides $\mathbf{5 a}$ and $\mathbf{5 b}$ were also suitable starting materials for the synthesis of $\alpha$-hydroxylated epoxides 4a,b under basic condition (for example, entry 6). The utilization of phosphate buffer is due to its ideal $\mathrm{pH}$ for the reaction with oxone $(\mathrm{pH} \sim 8,0)^{1}$ and the maintenance of the $\mathrm{pH}$ even when 2.5 equiv. Oxone was employed.

The hydroxylated epoxide $\mathbf{4 b}$ is of synthetic interest as the building block for the short synthesis of the natural product harzialactone ${ }^{3}(6$, Scheme 3$)$.

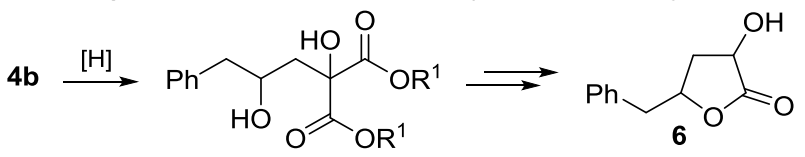

Scheme 3. Synthesis of harzialactone (6) from $\mathbf{4 b}$.

\begin{tabular}{|c|c|c|c|c|c|}
\hline \# & Malonate & $\begin{array}{l}\text { Oxone } \\
\text { (Equiv.) }\end{array}$ & $\begin{array}{l}\text { Basic } \\
\text { Cond. }\end{array}$ & Prod. & $\begin{array}{c}\text { Conv. } \\
(\%)^{\mathrm{a}}\end{array}$ \\
\hline 1 & $1 a$ & 1.3 & $\mathrm{NaHCO}_{3}{ }^{\mathrm{b}}$ & $2 a$ & 100 \\
\hline 2 & $1 b$ & 1.3 & $\mathrm{NaHCO}_{3}{ }^{\mathrm{b}}$ & $2 b$ & 100 \\
\hline 3 & 1c & 1.3 & $\mathrm{NaHCO}_{3}{ }^{\mathrm{b}}$ & 2c & 100 \\
\hline 4 & $3 a$ & 2.5 & Buffer & $4 a$ & $50^{d}$ \\
\hline 5 & $3 b$ & 2.5 & Buffer $^{c}$ & $4 b$ & 100 \\
\hline 6 & $5 a$ & 1.3 & Buffer ${ }^{c}$ & $4 a$ & 100 \\
\hline
\end{tabular}

Table. Hydroxylation of malonates $\mathbf{1 , 3}$ and 5

${ }^{a}$ Conversion was determined by ${ }^{1} \mathrm{H}$ NMR integration $(200 \mathrm{MHz})$.

b 4.7 equiv. of base was employed.

${ }^{c}$ Buffer $=1 \mathrm{~mol} \mathrm{~L}^{-1} \mathrm{~K}_{2} \mathrm{HPO}_{4} / \mathrm{KH}_{2} \mathrm{PO}_{4}, \mathrm{pH} 8$.

${ }^{d}$ Formation of the hydroxylated epoxide $\mathbf{4 b}$.

\section{CONCLUSION}

The hydroxylation of malonates $\mathbf{1}$ and $\mathbf{3}$ at the $\alpha$ carbon was achieved under mild conditions. The substituted malonates required buffer basic condition due to its better $\mathrm{pH}$ maintenance, giving hydroxylated epoxides 4. The optimization of the reaction conditions and the extension of this method to other substrates are under investigation.

\section{ACKNOWLEDGEMENTS}

INCT-CATÁLISE, CAPES, CNPq

\section{REFERENCES}

${ }^{1}$ Hussain, H.; Green, I. R.; Ahmed, I. Chem. Rev. 2013, 113, 3329.

2 Marques, M. V.; Oliveira, C. C.; Correia, C. R. D.; Sá, M. M. Abstract from 4th IICGC, 2012, Foz do Iguaçu, Brazil.

${ }^{3}$ Kumar, D. N.; Reddy, C. R.; Das, B. Synthesis 2011, 3190.

$15^{\text {th }}$ Brazilian Meeting on Organic Synthesis - 15 ${ }^{\text {th }}$ BMOS - November 10-13, 2013 - Campos do Jordão, Brazil 